\title{
SISTEM PEMULIAAN BERBASIS PEMBUDIDAYA (COOPERATIF BREEDING SYSTEM ): STRATEGI PEMULIAAN IKAN TEPAT GUNA
}

\author{
Wartono Hadie*) dan Lies Emmawati Hadie*) \\ *) Pusat Riset Perikanan Budidaya
}

\begin{abstract}
Abstrak
Pemuliaan berbasis pembudidaya memerlukan integrasi program dan pelaksanaan yang sinergis antar semua stakeholder. Pemikiran, pencurahan waktu, dan upaya bersama antar sesama pembudidaya (user), pemulia (breeder), dan pemerintah dalam konteks pemuliaan berbasis pembudidaya dapat mengatasinya. Program yang seksama, manajemen yang konsisten, dan pemahaman lingkungan yang cermat akan memberikan hasil yang menguntungkan. Dengan ikan unggul, pakan yang memadai, dan lingkungan optimal, pembudidaya bisa memperoleh keuntungan maksimal. Dewasa ini kenyataan menunjukkan bahwa penggunaan benih varietas unggul bermutu oleh kalangan pembudidaya skala besar dan kecil, ternyata pada umumnya masih rendah untuk semuajenis ikan. Perkecualian terdapat antara lain pada usaha perikanan swasta yang bergerak pada ikan salmon dan nila. Benih varietas unggul bermutu untuk banyak komoditi, bahkan masih mengimpor, dan menghabiskan devisa cukup besar. Selain menghabiskan devisa, impor jenis hanya akan menguntungkan bagi negara pengekspor jenis tersebut. Rendahnya tingkat penggunaan benih varietas unggul dan bermutu untuk segala macam komoditi pertanian termasuk perikanan sesungguhnya membuka peluang bagi industri perbenihan dalam negeri, baik yang masih dalam taraf penangkar, maupun industri benih yang sudah mampu membuat varietas unggul baru sendiri. Selama ini hampir semua varietas unggul baru dari berbagai komoditi, dihasilkan oleh kelembagaan penelitian Pemerintah dan Perguruan Tinggi.
\end{abstract}

KATA KUNCl: pemuliaan berbasis pembudidaya, cooperative breeding system, pembiakan kooperatif, strategi pemuliaan ikan

\section{PENDAHULUAN}

Sistem pemuliaan ikan di Indonesia baru dimulai pada akhir 1980-an yang dilakukan pada ikan mas. Oleh karena itu pemahaman yang sesungguhnya tentang pemuliaan belum dimiliki oleh para praktisi. Kendala utama adalah pengetahuan tentang sumber daya manusia (SDM), tujuan, metode, dan fasilitas dalam melakukan pemuliaan ikan secara benar. Pada era 1990-an metode telah berkembang sehingga telah diperoleh tahapan dasar yang harus diikuti. Tahapan yang ditetapkan meliputi koleksi, karakterisasi, seleksi dan multiplikasi. Dengan terbitnya UndangUndang No. 29 Tahun 2000, yang mengatur tentang perlindungan varietas (khususnya tanaman) dapat juga diacu oleh subsektor perikanan sebagai acuan dalam pengakuan kerja hasil pemuliaan dan perlindungannya oleh pemerintah. Dalam undang-undang tersebut juga secara jelas diakui keberadaan seorang pemulia, yang mencakup hak dan kewajibannya.

Pada akhirnya kendala umum yang dirasakan oleh unit pelaksana pemuliaan adalah keterbatasan sarana riset untuk pemuliaan. Dalam pelaksanaan pemuliaan dibutuhkan sarana yang memadai, dan kadang-kadang tidak cukup hanya mengandalkan kepemilikan dari satu lembaga riset. Dengan demikian agar pemuliaan dapat terlaksana dengan kaidah ilmiah yang benar, maka perlu ada kerja sama antara lembaga riset dengan masyarakat pembudidaya. Kerja sama ini tidak saja mencakup sarana atau fasilitas kolam, melainkan juga program, tujuan, maupun meto de pelaksanaan yang selanjutnya disebut sistem pemuliaan berbasis pembudidaya.

Strategi ini akan menyelesaikan beberapa kendala yang selama ini menjadi penyebab utama tidak berjalannya pemuliaan dengan cepat. Pemuliaan berbasis pembudidaya akan dapat membagi peran, tanggung jawab, dan beban finansial dalam melakukan pemuliaan. Namun demikian hasilnya akan secara cepat dirasakan oleh pengguna karena tujuannya merupakan tujuan bersama. Mengingat cara ini sangat strategis, maka pemuliaan berbasis pembudidaya ini juga suatu strategi yang tepat guna. 


\section{Kondisi Budidaya Perikanan di Indonesia}

Beberapa fenomena pemuliaan di negara maju dalam melaksanakan pemuliaan suatu komoditas adalah: menggunakan teknologi tinggi, metode yang sempurna dalam mengukur dan mengevaluasi hewan uji, tingkat pengorganisasian yang tinggi, berhasil dalam peningkatan manajemen genetik (Bruns, 2005).

Sementara itu di negara berkembang, kondisi pemuliaannya masih mengadopsi teknologi dari negara maju. Hal ini biasanya tidak tepat guna, beberapa hewan sebagai hasil kerja sama atau bantuan tidak terpelihara dengan baik, tidak runut atau tidak mampu membuat perencanaan dengan baik, dan tidak memperhatikan lingkungan budidaya (Solkner et al., 2000).

Dalam perkembangan dunia pemuliaan hewan, Bruns (2005) menjelaskan bahwa terdapat perbedaan manajemen yang menyolok dalam pelaksanaan pemuliaan antara negara maju dan negara berkembang. Dalam hal ini terdapat tiga kelompok berdasarkan pelakunya yaitu: program nasional, komersial, dan masyarakat.

Program pemuliaan nasional sangat umum, tidak spesifik, sangat hati-hati atau hampir tidak realistis. Program pemuliaan skala komersial direncanakan oleh perusahaan, mengutamakan pengembalian modal tanpa memperhatikan lingkungan dan aspek sosial. Program pemuliaan yang dilakukan di pedesaan diorganisir oleh masyarakat kecil (pembudidaya) pada level subsistem, dipengaruhi oleh musim, ketersediaan pakan, ada tekanan penyakit, pengorganisasian tingkat rendah, sistem pencatatan data kurang, input sistem produksi rendah, dugaan respons seleksi dalam galur rendah (Bruns, 2005).

Perkembangan budidaya perikanan di Indonesia telah sampai pada taraf pemanfaatan teknologi modern yang meliputi jenis-jenis ikan komersial. Patut dicermati bahwa ikan-ikan hasil budidaya kita telah dipasarkan ke pasar dalam negeri dan luar negeri. Udang sebagai contoh yaitu udang windu, udang galah, udang vanamei menjadi andalan utama dalam menjaring devisa. Bahkan beberapa jenis darinya tidak dapat memenuhi kuota ekspor karena perkembangan budidaya belum dapat memasok besarnya permintaan pasar.

Dilihat dari sudut pandang pemuliaan menurut Neidhardt et al. (1996), ada empat tingkatan hubungan antara pembudidaya dengan ikan berdasarkan pemahaman dan apa yang dipraktekkan oleh pembudidaya ikan yang ada kaitannya dengan kegiatan pemuliaan. Tingkat pertama disebut user, di mana pembudidaya hanya sebagai pengguna yang mengeksplotasi sejumlah ikan yang dimilikinya tanpa melakukan perbaikan apapun. Usaha yang dilakukan biasanya hanya sebatas melindungi terhadap gangguan. Tingkat kedua adalah keepers, pada tingkat ini pemilik ikan telah memahami kebutuhan dasar ikan dan memenuhinya sehingga mengharapkan hasil yang lebih baik. Tingkat ketiga adalah producer, pada tingkat ini pembudidaya telah dapat memanfaatkan induk-induk dengan perawatan dan perhatian yang cukup untuk memproduksi benih dan induk. Tingkat yang terakhir adalah breeder, pada tingkatan ini pembudidaya (pemulia) telah memiliki pemahaman yang baik akan akidah pemuliaan serta mampu menerapkan pengetahuan dan teori pemuliaan dengan baik (Solkner et al., 2000). Sebagai konsekuensi atas tingkatan dalam kemampuan tersebut makajika pemerintah ingin mengadakan program bantuan sehubungan dengan program pemuliaan, satu hal yang harus diingat adalah bahwa user tidak mungkin meloncat pengetahuan dan keterampilannya menjadi producer bahkan breeder hanya dalam waktu satu atau dua tahun. Hal ini hendaknya menjadi bahan pertimbangan dalam pelaksanaan program pemerintah sehubungan dengan program pemuliaan.

\section{Status Kini Pemuliaan Perikanan di Indonesia}

Tujuan definitif dari pemuliaan untuk produksi ikan berkelanjutan, semata-mata bukanlah pertimbangan pasar seperti halnya nilai pasar produk pemuliaan, tetapi juga harus mempertimbangkan segi etis (ethical). Kebutuhan untuk jangka panjang yang merupakan suatu tujuan yang ditetapkan adalah tujuan biologis, ekologis, dan sosiologis. Hal ini dikarenakan tujuan pemuliaan hewan kadangkala ditetapkan hanya oleh permintaan pasar sesaat atau jangka pendek dan menyebabkan efek samping yang tidak diinginkan, biasanya berupa ancaman terhadap plasma nutfah.

Pemeliharaan diawali dengan domestikasi dan breeding serta respons seleksi terhadap cepat tumbuh telah diupayakan dalam banyak kegiatan pemuliaan ikan. Dari beberapa laporan Olsen et al. (2005) menyatakan bahwa respons seleksi untuk sifat laju pertumbuhan dari beberapa jenis ikan berkisar antara 4\%dan 20\% Selain itu, Tave (1995) menganjurkan untuk memperhatikan heritabilitas di atas 0,25 agar respons terhadap seleksi lebih baik.

Tujuan pemuliaan lebih jauh mencakup kesehatan ikan dan trait fungsional selain trait produksi yang telah direncanakan. Dasar ilmu seperti hak asasi hewan (animal welfare) dan pemahaman terhadap kelainan tingkah laku ikan juga sangat dibutuhkan agar manusia bertanggung jawab dari segi etik. Kurang dari 1\%material ikan dalam akuakultur pada tahun 1993 berasal dari program seleksi. 
Banyak dari program pemuliaan spesies yang diseleksi, hanya sedikit sekali yang dapat berjalan dengan baik karena pada umumnya tidak memiliki ukuran populasi efektif yang mencukupi. Walaupun demikian masih banyak dari jenis yang tidak mencapai perbaikan genetik yang maksimal ini mencapai banyak pasar. Hal ini pada akhirnya akan menimbulkan masalah baru, yakni penurunan keragaman genetik pada jenis tersebut. Inbreeding yang berkepanjangan dan kehilangan variasi genetik karena erosi genetik (genetic drift) akan berpengaruh terhadap keragaan jenis dan perkembangan genetik selanjutnya. Suatu populasi yang mencukupi jumlahnya dan keragaman genetik yang tinggi dengan struktur famili yang direncanakan merupakan kebutuhan pokok jika ingin melakukan kegiatan pemuliaan.

Hal penting yang perlu diperhatikan sebelum melakukan program pemuliaan untuk program produksi berkesinambungan adalah perencanaan yang baik, didukung oleh kebijakan pemerintah, memikirkan dan memperdulikan prinsip akuakultur, alam, dan sosial serta menerapkan prinsip dalam UU No. 29/2000 dan UU No. 12/1992. Suatu pandangan yang sifatnya umum di seluruh dunia didasari epistemologis dan ontologis yang holistik adalah hal yang dibutuhkan dalam program pemuliaan ikan.

Langkah-langkah dalam pemuliaan ikan yang telah disepakati dapat dijadikan pedoman dalam pelaksanaan pemuliaan ikan adalah sebagai berikut:

1. Koleksi. Jika jenis ikan telah menjadi jenis ikan budidaya, maka berarti langkah ini telah terlewati. Jika belum maka koleksi plasma nutfah merupakan awal dari langkah budidaya.

2. Karakterisasi dan evaluasi. Langkah ini terdiri atas dua makna yaitu memperoleh karakter ikan sesungguhnya dan yang kedua adalah mengevaluasi keragaan dari sifat genetiknya dalam budidaya.

3. Domestikasi. Langkah ini sesungguhnya adalah suatu alat untuk memperkenalkan plasma nutfah kedalam jajaran ikan budidaya, yang diterima di masyarakat sesuai fitur harapan.

4. Pengembangan budidaya di masyarakat. Langkah ini akan berkembang sesuai kondisi masyarakat yang menerima. Ada jenis ikan yang perkembangannya sangat cepat karena preferensi masyarakat tinggi dan atau nilai komersial yang tinggi. Tetapi ada juga suatu jenis atau komoditas yang perkembangannya tidak cepat karena hanya dibutuhkan oleh sedikit masyarakat atau karena nilai ekonomi yang kurang tinggi.

5. Pemuliaan. Langkah ini akan diambil karena pada umumnya kondisi genetik ikan budidaya sudah begitu merosot sehingga tidak lagi menguntungkan. Pada langkah inilah pemuliaan beraksi, dengan tujuan yang jelas yakni untuk memulihkan atau bahkan meningkatkan keunggulan genetik jenis ikan tersebut.

6. Pelepasan jenis/varietas. Langkah ini merupakan usaha untuk memperkenalkan jenis baru kepada pembudidaya atau mengganti jenis yang sudah turun mutunya. Inipun biasanya masih pro-kontra sebelum jenis hasil pemuliaan tersebut terbukti sebagai fitur ikan yang diharapkan.

Ada beberapa jenis ikan yang telah dirilis pemerintah melalui Menteri Kelautan dan Perikanan yaitu udang galah yang merupakan rilis varietas. Sedangkan kelompok kedua yang merupakan rilis jenis lokal adalah patin jambal (Pangasius djambal), dan ikan mas. Jenis introduksi adalah patin siam (Pangasius hypophthalmus), lele dumbo (sangkuriang), udang vanamei (Penaeus vannamei), udang stilorostris (M etapenaeus stylorostris), dan lobster air tawar (Cherax quadricarinatus). Jenis-jenis tersebut sekarang telah berkembang di masyarakat sebagai ikanikan budidaya.

Selama ini pemuliaan dilakukan oleh institusi pemerintah yang berada di bawah Badan Riset Kelautan dan Perikanan dan Direktorat Jenderal Perikanan Budidaya. Di beberapa unit kerja, kadang-kadang tidak tersedia tenaga pemulia yang secara khusus menangani hal tersebut. Oleh karena itu, tenaga pemulia sebagai legalitas atas rilis tersebut perlu membantu unit kerja Lembaga Penyelenggara Pemuliaan (LPP/P) yang bersangkutan. Dengan demikian rilis varietas maupun jenis telah memenuhi standar yang berlaku (UU No. 12, 1992; PP 44, 1995).

Pemuliaan beberapa jenis ikan (Gambar 1) sebagai contoh dari hasil kerja yang dilakukan oleh Lembaga Penyelenggara Pemuliaan (Badan Riset Kelautan dan Perikanan), telah melaksanakan pemuliaan ikan mas sejak pertengahan tahun 1980 dan telah merilis jenis ikan mas rajadanu pada tahun 2001. Udang galah telah melakukan kegiatan pemuliaan sejak pertengahan tahun 1990 dan telah merilis varietas udang galah GIMacro pada tahun 2001 (Hadie et al., 2001).

\section{Pemuliaan Berbasis Pembudidaya}

Filosofis dari suatu program pemuliaan adalah meningkatkan breeding value dari suatu populasi. Selanjutnya tujuan dari pemuliaan itu sendiri dapat berbeda-beda sesuai permintaan pengguna seperti laju pertumbuhan, efisiensi pakan, tahan penyakit, edible portion, karkas, warna, dan lain sebagainya. Ini semua harus betul-betul menjadi landasan dalam pelaksanaan pemuliaan agar ada keberlanjutan usaha. 

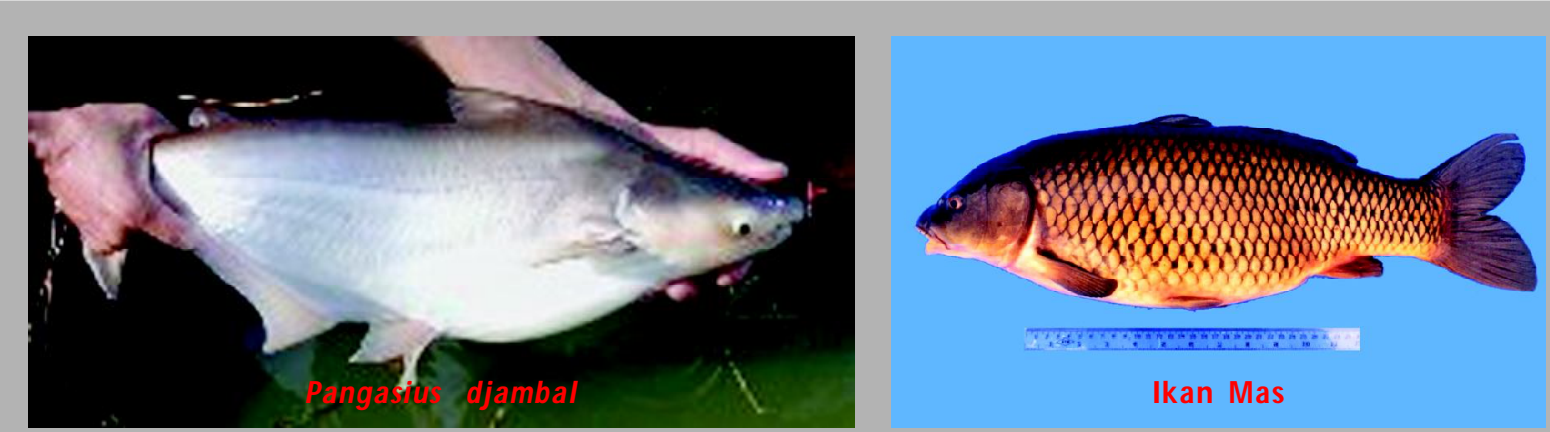

Ikan Mas
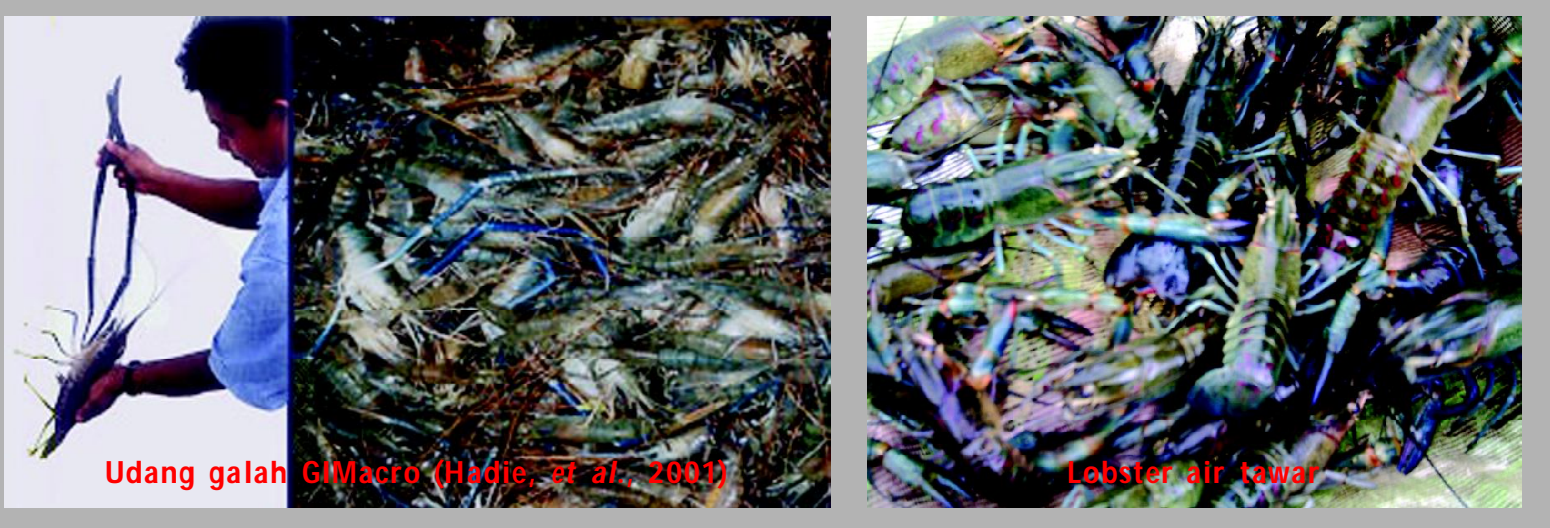

Gambar 1. Beberapa jenis dan varietas ikan dan yang telah dirilis Departemen Kelautan dan Perikanan

Industri perbenihan nasional tidak akan tumbuh dan berkembang apabila tidak terdapat jaminan perlindungan terhadap produk varietas unggul baru yang mereka hasilkan. Jaminan yang merupakan hak khusus yang eksklusif untuk mengeksploitasi varietas unggul baru yang dibuatnya, dikenal pula sebagai hak perlindungan varietas tanaman atau juga dikenal sebagai Hak Pemulia Tanaman (plant breeder's right). Hak tersebut merupakan salah satu bentuk hak intelektual, seperti hak paten, hak cipta, hak tentang merek, hak tentang disain tata letak sirkuit terpadu, disain industri, dan hak tentang rahasia dagang (Baihaki, 2006). Di sektor perikanan, hal ini belum dilaksanakan hingga sekarang karena kita belum sepenuhnya mengacu kepada undang-undang yang ada.

Pemuliaan berbasis pembudidaya memiliki pengertian bahwa kegiatan ini dilakukan secara bersama-sama dan memanfaatkan sumber daya ikan yang dimiliki oleh pembudidaya. Pemuliaan ikan berbasis pembudidaya adalah suatu metode pemuliaan tepat guna karena memiliki visi dan misi yang sama antar semua pelaku baik oleh pemerintah yang memiliki tanggung jawab terbesar, maupun pembudidaya sebagai pengguna hasilnya.

M enarik mencermati adanya standar rilis suatu varietas atau rilis jenis, karena setiap peristiwa rilis tersebut harus ada tenaga pemulia yang diakui kepakarannya. M engapa demikian, pengujian suatu varietas maupun jenis baru memerlukan perlakuan dan data ilmiah (scientific data) yang kepakarannya hanya dimiliki oleh pemulia yang memenuhi standar pemerintah (UU No. 12, 1992). Terdapat pro-kontra sebenarnya, di satu sisi pelepasan varietas, jenis lokal, dan introduksi mengacu kepada UUPVT yang memungkinkan badan atau perorangan dapat melakukan rilis ini. Namun di sektor perikanan belum terdapat aspek legal yang melindungi kegiatan ini. Dengan acuan ini beberapa instansi pemerintah telah mengubah tugas pokoknya untuk merilis jenis/varietas dengan atau tanpa tenaga pemulia.

Dalam program pemuliaan ikan berbasis pembudidaya ini ada tiga komponen yang menentukan dan akan bekerja bersama-sama yaitu swasta, perorangan, dan pemerintah (Gambar 2). Ketiganya bisa bertindak sendiri-sendiri tetapi terangkai dalam satu koridor. Beberapa keuntungan di antaranya adalah murah dan mudah berkembang pasca rilis karena telah memenuhi kebutuhan yang dirumuskan bersama. Sudah saatnya masyarakat perikanan Indonesia bersatu padu menggalang potensi untuk membangun industri pemuliaan sebagai soko guru berkembangnya perikanan budidaya di Indonesia.

Hingga saat ini belum terlihat minat investor untuk membiayai penelitian pemuliaan di bidang perikanan. Namun begitu sudah ada minat yang muncul secara 


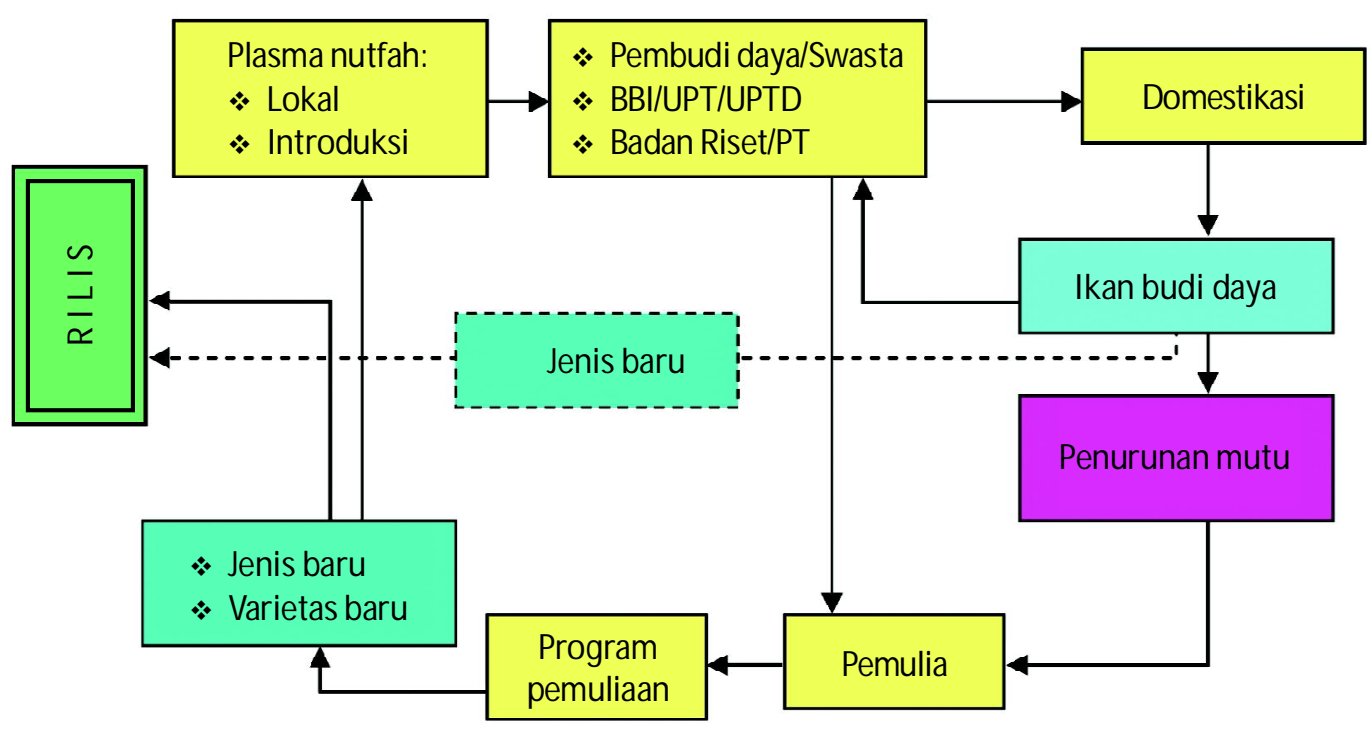

Gambar 2. Bagan alir pemuliaan berbasis pembudi daya dengan tujuan rilis jenis maupun varietas baru ( $-\rightarrow$ ikan potensial dan telah siap diterima masyarakat; $\longrightarrow$ jalur normal plasma nutfah hingga budi daya)

sporadik untuk melakukan pemuliaan dengan pengertian dan kemampuannya sendiri-sendiri. Ini merupakan potensi awal yang baik untuk berkembangnya pemuliaan di Indonesia. Oleh karena pengaturannya harus segera dilakukan agar mendapatkan hasil yang cepat terintegrasi dan dapat dipertanggungjawabkan.

Pemuliaan berbasis pembudidaya akan melibatkan banyak para pihak (stakeholder) yang bekerja sama dalam satu koordinasi. Koordinasi dan pengawasan penyelenggara pemuliaan berada di bawah Badan Riset atau Perguruan Tinggi yang memiliki tenaga pemulia. Penyelenggara pemuliaan menetapkan tujuan akhir berupa fitur ikan yang akan dihasilkan. Tujuan tersebut telah disepakati semua elemen yang bersatu menyusun standar prosedur operasional pemuliaan yang mencakup mekanisme pengawasan dan pengendalian mutu (UU No. 29, 2000).

Penyilangan antar tetua untuk kebutuhan seleksi dilakukan oleh Lembaga Riset sebagai penyelenggara pemuliaan. Hasilnya kemudian dibagikan kepada para partisipan yaitu para pembudidaya maupun swasta ataupun UPT. Pada waktu ikan mencapai ukuran calon induk, partisipan melakukan seleksi atas dasar kriteria yang telah disepakati.

Komersialisasi hasil pemuliaan sangat ditunggu agar segera dapat dinikmati oleh masyarakat pembudidaya maupun industri. Untuk hal ini maka dalam kelembagaan penyelenggara pemuliaan dapat terdiri atas lembaga komersial yang berfungsi sebagai penggerak ekonomi dari hasil penelitian ini (Gambar 3).
Sebagai contoh bagaimanajika hasil suatu pemuliaan yang berpotensi ini tidak secara cepat diketahui oleh pembudidaya. Dalam hal ini mitra komersial dapat memperkenalkan kepada pembudidaya tentang hasil penelitian pemuliaan yang sudah siap dikembangkan. Sistem demikian sangat efektif dan telah dilakukan di beberapa negara (Gambar 4).

Mekanisme dalam pelaksanaan seleksi adalah sebagai berikut:

a. Lembaga riset yang telah memiliki program seleksi memberikan sejumlah induk yang memenuhi standar $\mathrm{N}_{\mathrm{e}}$ kepada mitra (swasta, industri, atau UPR) untuk menghasilkan keturunan

b. Keturunan yang dihasilkan dari masing-masing mitra, sebanyak 25\%terseleksi dikembalikan ke Lembaga Riset sebagai bahan seleksi di Lembaga Riset

\section{RANCANGAN PEMBIAKAN KOOPERATIF}

Cooperative Breeding System (CBS), yang selanjutnya akan dikenalkan sebagai pemuliaan berbasis pembudidaya (PBP) dihasilkan dari pemikiran berdasarkan prinsip genetik, di mana seleksi yang lebih ketat akan dapat diterapkan terhadap populasi yang lebih besar dibandingkan dengan populasi kecil.

Sebenarnya tidak ada alasan bagi pembudidaya kecil untuk tidak bergabung dengan pemerintah secara bersama mendapatkan hasil yang maksimal. Prinsip dari rancangan CBS sangat sederhana seperti yang dilukiskan pada Gambar 5. Dalam hal ini terlihat bahwa induk ikan betina dari pembudidaya yang berbeda besarnya 


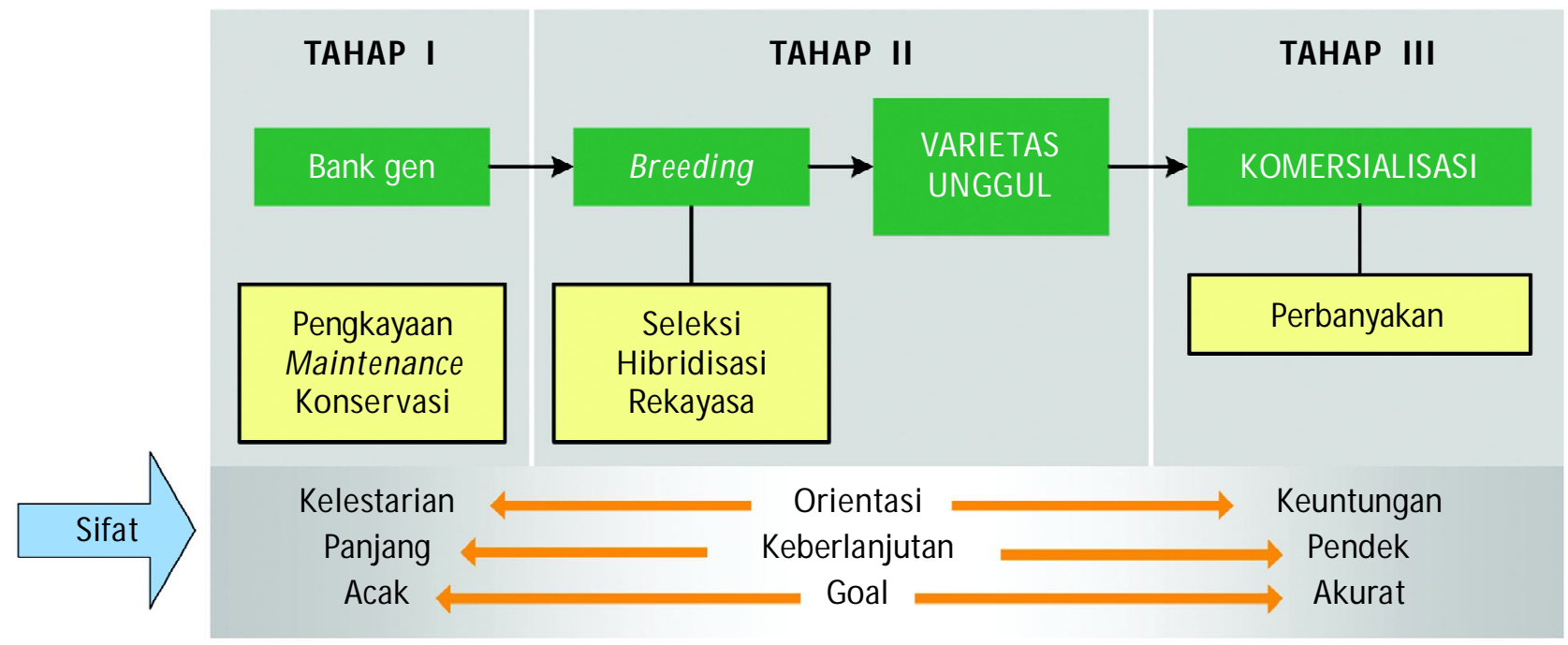

Gambar 3. Sifat kerja sama menurut tahapan pemuliaan (Deptan, 2006)

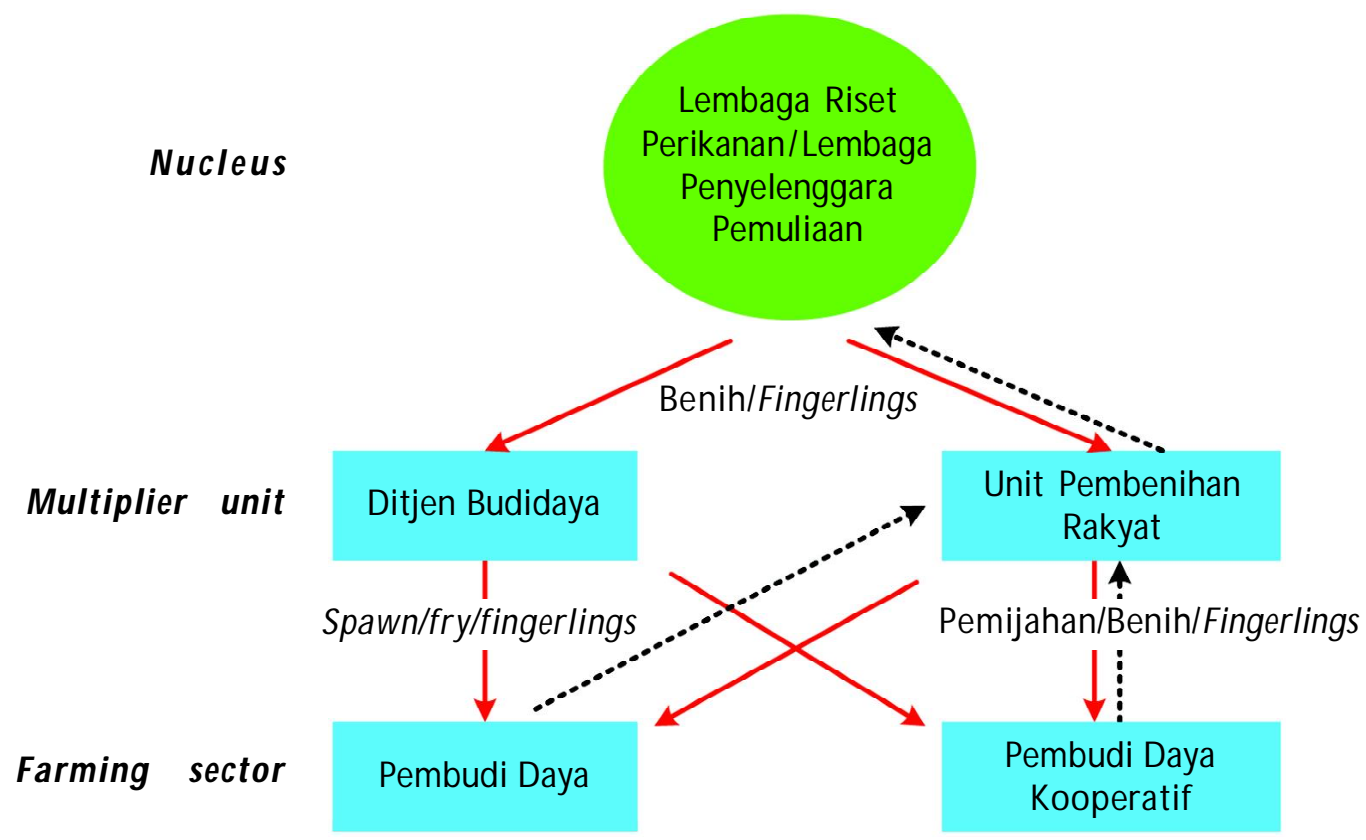

Gambar 4. Diagram pelaksanaan tugas pemuliaan berbasis pembudi daya.

...- Jalur bahan seleksi; $\longrightarrow$ Jalur hasil seleksi (Reddy, 1999)

(ukurannya) diseleksi dan yang terbaik akan masuk ke pusat pembenihan dan demikian pula dengan induk jantan dari pusat pembenihan akan keluar ke masing-masing pembudidaya.

Secara rinci kegiatan keseluruhan dari CBS ini adalah sebagai berikut:

a. Di dalam pembenihan setiap pembudidaya menyeleksi induk ikannya masing-masing. Induk betina dengan ranking tertinggi akan dikirim ke pusat pembenihan

b. Seluruh sistem untuk mencatat dan meranking yang dilaksanakan oleh pembudidaya harus memiliki standar yang sudah ditentukan untuk mencegah terjadinya kesalahan-kesalahan dalam penentuan nilai mutu

c. Harus ditentukan terlebih dahulu di mana pusat pembenihan tersebut akan dibangun dan bagaimana mengelolanya. Juga harus ditentukan bagaimana sistem atau peraturan mengenai ikan-ikan yang keluar masuk pembenihan dari dan ke pembudidaya. Apakah pembudidaya harus membayar selama ikannya berada di pusat pembenihan atau ditukar, semua ini harus ditentukan terlebih dahulu 


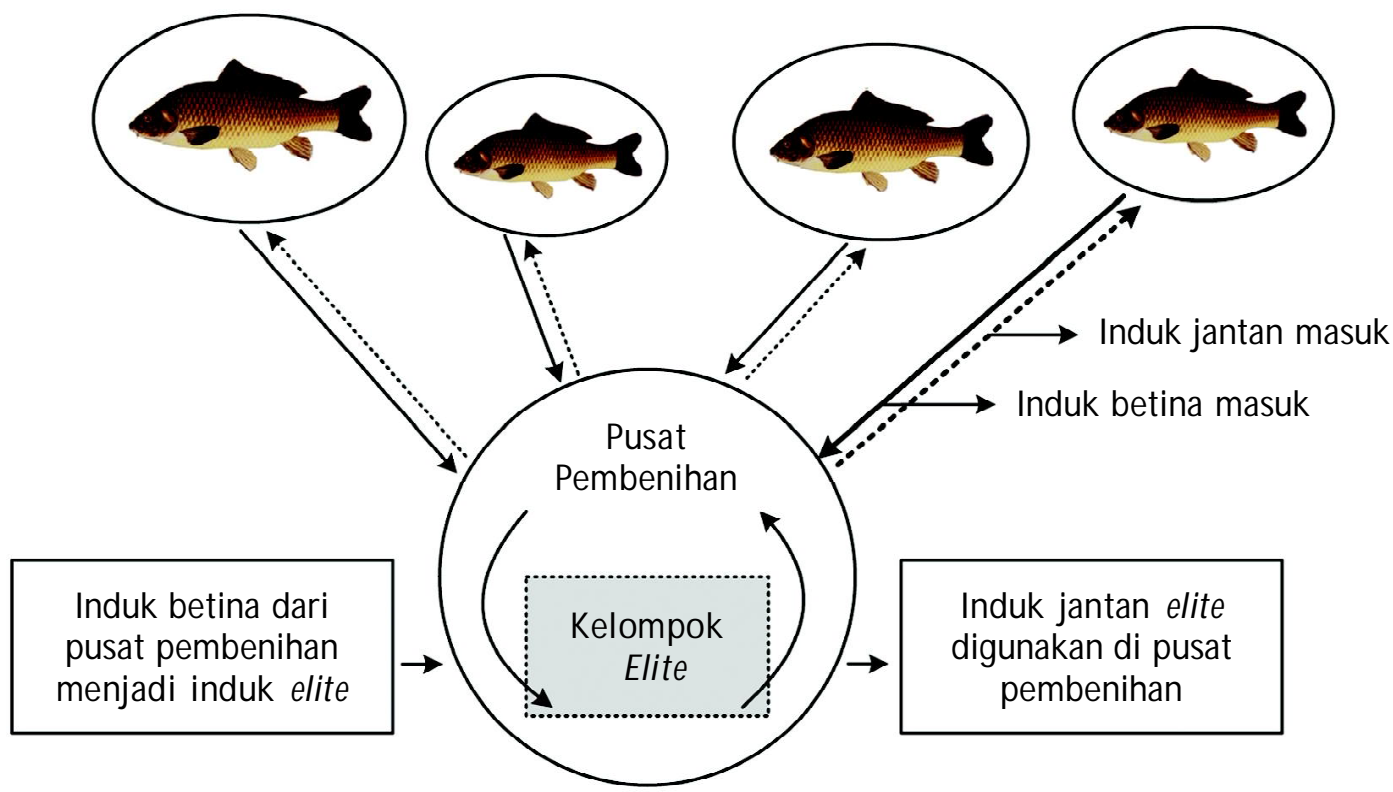

Gambar 5. Rancangan pemuliaan berbasis pembudi daya (Pane, 1993)

d. Seleksi untuk pemilihan induk betina terbaik tetap dilakukan baik pada pembudidaya maupun pusat pembenihan. Pada awalnya penggantian ikan di pusat pembenihan berasal dari ikan yang paling baik dari pembudidaya, selanjutnya dipakai sebagai pengganti, sebagian berasal dari pusat pembenihan, dan akhirnya seluruh penggantian dapat berasal dari pusat pembenihan

e. Di dalam pusat pembenihan induk betina terbaik akan dipindahkan ke kelompok elit dan untuk seterusnya data-data prestasinya tetap diikuti. Induk-induk kelompok elit ini harus dipijahkan dengan pejantan terbaik yang kelak menghasilkan pejantan yang akan dipakai di pusat pembenihan

Gambaran yang diberikan di atas tentu saja tidak atau belum secara terinci melukiskan apa saja yang harus dilakukan dan bagaimana cara melakukannya. Pada umumnya pelaksanaan yang dilakukan di pusat pembenihan dan kelompok elit tergantung dari kesepakatan para pembudidaya mengenai parameter apa dan bagaimana serta berapa besar produk yang akan dihasilkan. Apakah pusat pembenihan akan dilakukan tes prestasi (performance test), tes keturunan (progeny test) tergantung kesepakatan, dan kebutuhan teknisnya (Chagunda \& Mushota, 2005).

Dalam mengelola pusat pembenihan, hal penting yang harus diingat adalah bahwa sebagian besar hasil kemajuan genetik yang akan dicapai tergantung dari tingginya kemampuan seleksi (berhasil menyeleksi yang terbaik) yang dilaksanakan pada tahap-tahap pertama. Setelah ini kemajuan genetik akan tergantung dari ketepatan seleksi oleh para pembudidaya dan pusat pembenihan.

$\mathrm{Hal}$ yang sangat menarik dari sistem ini adalah terciptanya potensi pendidikan dan bimbingan yang sangat baik. Pada waktu-waktu tertentu para pembudidaya harus berkumpul untuk membicarakan dan menyeleksi ikan mereka membicarakan cara dan sistem yang mereka lakukan masing-masing dalam mengelola ikannya. Pandangan mereka tentang hal-hal tertentu dalam budidaya sangat membantu satu sama lain.

Sistem seperti ini telah dilakukan masyarakat peternak di Australia dalam peternakan sapi dan biri-biri. Di sana hal ini menjadi salah satu faktor penunjang majunya usaha peternakan di negara tersebut. Di negara-negara di mana banyak terdapat para pembudidaya yang kuat dan maju, sistem ini dapat diterapkan secara mandiri tanpa ikut campur pemerintah yang berarti. Di negara berkembang terdapat pembudidaya yang lemah di mana setiap pembudidaya hanya memiliki induk di bawah 10 ekor, akan sangat sulit dilakukan. Selain jumlah induk yang relatif sedikit, keterampilan pembudidaya juga terbatas.

Di Indonesia cara ini belum dilakukan mengingat cara dan sistem pelaksanaannya belum banyak dipikirkan baik oleh pembudidaya maupun pemerintah. Namun demikian setelah memahami konsep pemuliaan berbasis pembudidaya, hal ini diharapkan akan segera terwujud. Dengan demikian diharapkan di masa datang mutu benih ikan tidak lagi menjadi hambatan utama perkembangan budidaya perikanan di Indonesia, karena faktor benih termasuk dalam fixed cost dalam produksi. 
Pada Tabel 1 terlihat bahwa kelanjutan dari pengembangan ikan hasil pemuliaan bisa mendapat hambatan jika pemilihan objek pemuliaan berjalan searah dari pemulia. Sebaliknya jika pemilihan objek berasal dari kompromi pengguna dan pemulia akan memberikan jaminan pengembangan ikan hasil pemuliaan lebih baik. Kombinasi ini adalah yang paling ideal, walaupun kadang-kadang timbul masalah jika menggunakan mitra yang banyak. Oleh karena itu, yang paling ideal adalah membuat kesepakatan tujuan dari pemuliaan dan memilih komoditas secara bersama antara pemulia dan pengguna.

Pada Gambar 6 terlihat bahwa mekanisme pemuliaan membagikan beban pekerjaan kepada semua partisipan dengan tanggung jawab terbesar berada di pihak pemerintah. Dengan pekerjaan demikian perolehan hasil akan dipercepat dan apapun hasilnya akan segera diterima masyarakat karena telah menjadi tujuan utama secara bersama dan merupakan keinginan pengguna secara kolektif.

Tabel 1. Beberapa model pelaksanaan pemuliaan ikan berbasis pembudi daya (Deptan, 2006)

\begin{tabular}{|c|c|c|c|}
\hline Model & $\begin{array}{l}\text { Pelaksana } \\
\text { pemuliaan }\end{array}$ & Konsumen sasaran & Keterangan \\
\hline I & Pemulia & $\begin{array}{l}\text { Kons. } 1 \text { (pengusaha) } \\
\longrightarrow \text { kons. } 2 \text { (pembudi daya) } \\
\rightarrow \text { kons. } 3 \text { (Konsumen akhir) }\end{array}$ & $\begin{array}{l}\text { - Pemulia menawarkan varietas unggul } \\
\text { - Risiko tidak laku }\end{array}$ \\
\hline$\|$ & $\begin{array}{l}\text { Pemulia + } \\
\text { Mitra (kons. 1) }\end{array}$ & Kons. $2 \longrightarrow$ kons. 3 & $\begin{array}{l}\text { - Varietas unggul sesuai selera pasar } \\
\text { - Risiko tergantung kesepakatan }\end{array}$ \\
\hline III & $\begin{array}{l}\text { Pemulia }+ \\
\text { Pembudi daya } \\
\text { (kons. 2) }\end{array}$ & Konsumen 3 & $\begin{array}{l}\text { - Sulit diterapkan karena melibatkan } \\
\text { banyak mitra; } \\
\text { - Masih mungkin diterapkan dengan } \\
\text { kesepakatan tujuan }\end{array}$ \\
\hline
\end{tabular}

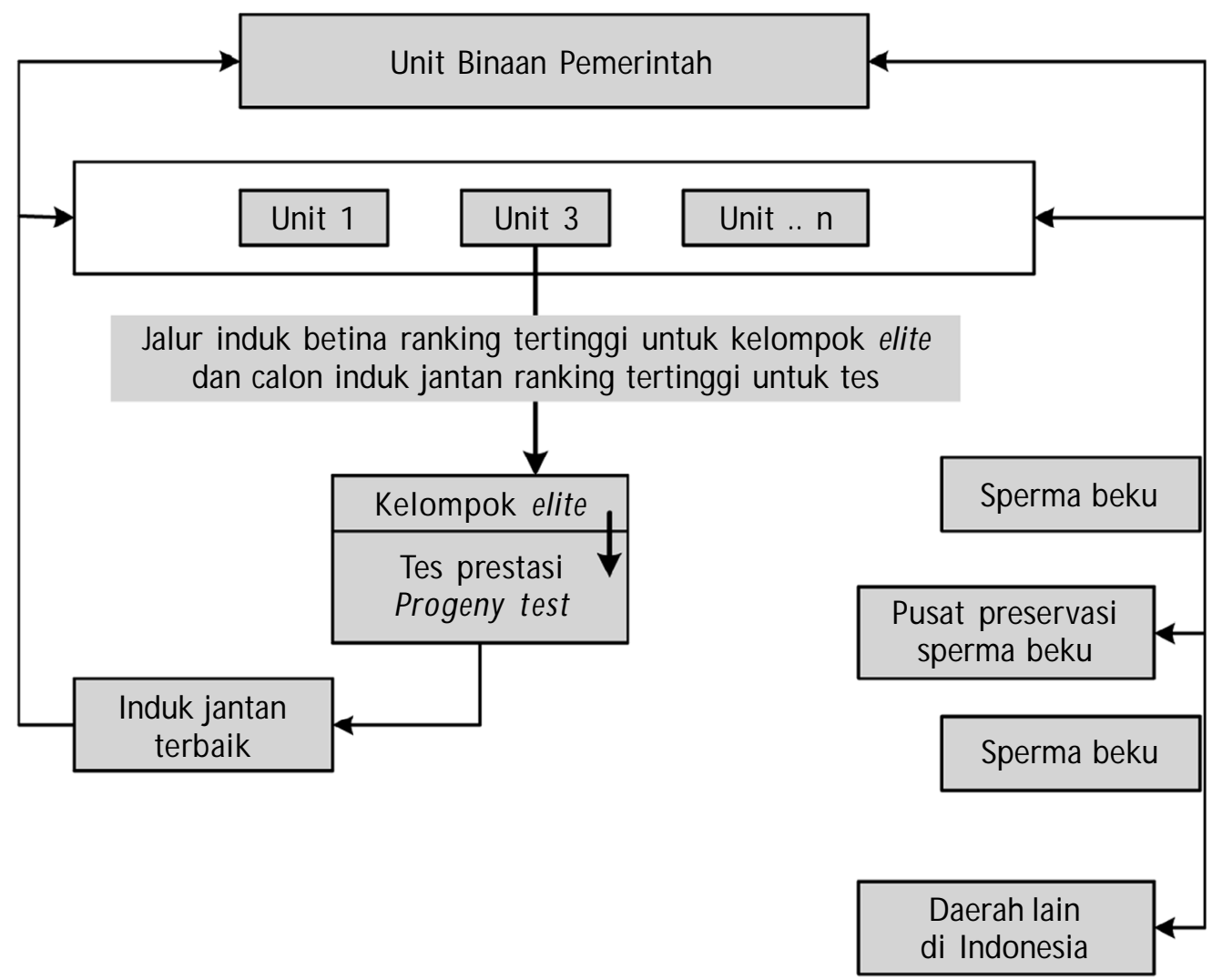

Gambar 6. Skema pusat pembenihan dan mekanisme kerjanya (Pane, 1993) 


\section{Tata Cara Rilis}

Di bidang perikanan, pemuliaan dan varietas ikan belum mendapat perhatian cukup serius dibanding dengan varietas tanaman yang telah diatur dalam undang undang (UU No. 29 tahun 2000).

Dalam penyelenggaraan rilis bidang perikanan baik varietas, jenis, maupun introduksi, pemerintah belum menetapkan aturan baku yang dapat diikuti oleh instansi yang bergerak di bidang pemuliaan. Hal ini akan berdampak kepada pengemban tugas pemeliharaan induk sebar, benih bina, perlindungan varietas, dan lain-lain. Selama ini semua bidang tersebut bernaung kedalam undang-undang perlindungan varietas tanaman (PP No. 14, 2004). Dengan demikian peran pemerintah terhadap pembinaan, perlindungan terhadap hasil karya pemuliaan tidak dominan dan menjamin.

Jaminan pemerintah terhadap perlindungan varietas (Gambar 7) akan merupakan jaminan hukum bagi pemulia untuk menghasilkan dan memanfaatkan hasil karyanya berupa varietas.

Dengan pola seperti di atas jaminan hukum terhadap lembaga yang bergerak di bidang pemuliaan, hak atas varietas, jalur pembinaan benih maupun induk hasil pemuliaan menjadi lebih jelas. Demikian juga antara

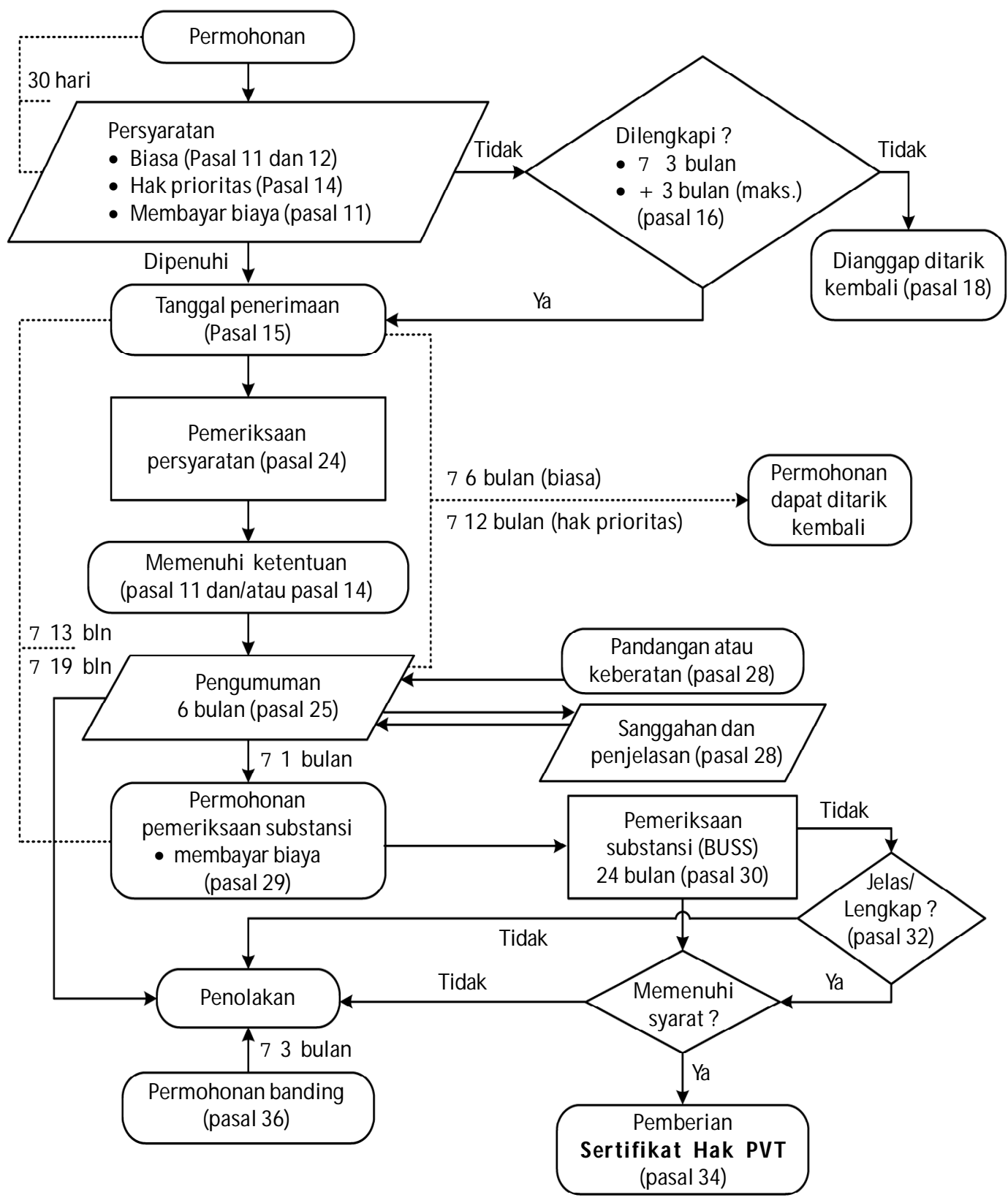

Gambar 7. Prosedur permohonan hak atas perlindungan varietas tanaman (Deptan, 2004) 
lembaga riset penghasil varietas dan lembaga pengembang dan pemelihara hasil pemuliaan menjadi lebih jelas dan tidak tumpang tindih.

\section{KESIMPULAN}

Pemuliaan berbasis pembudidaya merupakan salah satu strategi baru dalam upaya perbaikan mutu ikan yang dilakukan secara bersama-sama oleh pemerintah (pemulia) dan masyarakat untuk menciptakan ikan unggul yang dapat diterima oleh masyarakat. Pemuliaan berbasis pembudidaya akan menjadi cara yang tepat guna, murah, mudah, dapat segera memenuhi kebutuhan masyarakat karena hasilnya telah memenuhi selera pengguna.

\section{DAFTAR PUSTAKA}

Baihaki, A. 2006. Manfaat dan Implementasi UU No. 29 Tahun 2000 Tentang Pvt dalam Pembangunan Industri Perbenihan. Makalah disampaikan pada Kongres Komisi Daerah Plasma Nutfah se Indonesia, Komisi Nasional Plasma Nutfah, Balitbang Deptan, 31 Juli-2 Agustus 2006, di Balikpapan, Kaltim. 10 pp.

Bruns, E.W. 2005. Village Breeding Programs and Smallholde Recording Systems. Institute of Animal Breeding and Genetics George-August-University of Goettingen Albrecht-Thaer-Weg 3, 37075, Goettingen, Germany. 19 pp.

Chagunda, M.G.G. and N. Mushota. 2005. The framework for a smallholder recording system in Sub Saharan African countries Department of Animal Science, Bunda College of Agriculture, University of Malawi, P.0. Box 219, Lilongwe, Malawi. 18 pp.

Departemen Pertanian. 2004. Pusat Perlindungan Varietas Tanaman, Departemen Pertanian Republik Indonesia. http://database1.deptan.go.id/ppvt/pelayanan/ prosedur_pvt.php.
Departemen Pertanian. 2006. Panduan Umum Model dan Prosedur Kerjasama Pemuliaan Partisipatif Pertanian Badan Penelitian dan Pengembangan Pertanian. http://www.litbang.deptan.go.id/special/raker06/ P04.ppt. 34 pp.

Hadie, L.E., W. Hadie, I.I. Kusmini, Jaelani, B. Gunadi, dan H. Supriyadi. 2001. Naskah Pelepasan Varietas Udang Galah GIMacro. Pusat Riset Perikanan Budidaya. Badan Riset Kelautan dan Perikanan. Departemen Kelautan dan Perikanan. 8 pp.

Neidhardt, R., G. Grell, W. Schrecke, and H. Jakob. 1996. Animal research and development. 43(44): 44- 52.

Olsen, E.M., G.R. Lilly, M. Heino, M.J. Morgan, J. Brattey, and U. Dieckmann. 2005. Assessing changes in age and size at maturation in collapsing populations of Atlantic cod (Gadus morhua). Can J Fish Aquat Sci. 62: 811-823.

Pane, I. 1993. Pemuliabiakan ternak sapi. Penerbit PT Gramedia, Jakarta. 155 pp.

Peraturan Pemerintah Republik Indonesia Nomor 44 Tahun 1995. Tentang Pembenihan Tanaman. 5 pp.

Reddy, P.V.G.K. 1999. Genetic resources of Indian major carps. FAO Fisheries Technical Paper. No. 387. Rome, FAO. $76 \mathrm{pp}$.

Solkner, J., H. Nakimbugwe, and A.V. Zarate. 2000. Analysis of determinants for success and failure of village breeding programes. Animals conference. $6 \mathrm{pp}$.

Tave, D. 1995. Selective breeding programmes for medium-sized fish farms. FAO Fisheries Technical Paper 352. Rome. $122 \mathrm{pp}$.

Undang-Undang Republik Indonesia Nomor 12 Tahun 1992. Tentang Sistem Budidaya Tanaman. 38 pp.

Undang-Undang Republik Indonesia Nomor 29 Tahun 2000. Tentang Perlindungan Varietas Tanaman. 42 pp. 